\title{
The Role of Market Orientation in Innovation of Bodybuilding Clubs
}

\author{
${ }^{1}$ Nasser Bai ${ }^{*}{ }^{2}$ Habib Asgharpour, ${ }^{2}$ Akram Esfahani Nia
}

${ }^{1}$ Department of Physical Education and Sports Sciences, Azadshahr Branch, Islamic Azad University, Azadshahr, Iran. ${ }^{2}$ Department of Physical Education and Sports Sciences, Aliabad Katoul Branch, Islamic Azad University, Aliabad Katoul, Iran.

\begin{abstract}
Today, market orientation plays a vital role in determining customers' needs and success of organizations. Market orientation has also influenced various organizations' measures including innovation. Therefore the aim of this research is to study the role of market orientation in innovation of bodybuilding clubs of Golestan Province. The population of this study comprised all 170 managers of bodybuilding clubs of Golestan province and the sample size was determined based on Cochran formula and stratified random selection method (119 manager). Market orientation questionnaires of Ramayah et al. (2011) and innovation questionnaires of Carmen and Maria Jose (2008) were employed for collection of study data. Smart PLS was used to analyze data and identify the effects of research variables of structural equation modeling. Results revealed that competitor orientation is not effective on innovation of bodybuilding clubs, but the effect of coordination between tasks and customer orientation on innovation of bodybuilding clubs was significant. Concerning the results, it is suggested that the managers of bodybuilding clubs of Golestan province provide more innovation by improving and developing market orientation in their clubs.
\end{abstract}

KEY WORDS: Market Orientation, Competitor Orientation, Customer Orientation, Innovation, Bodybuilding Clubs.

\section{INTRODUCTION}

Every business is customer-driven. There will be no business without customers. Organizations and companies, whether manufacturing or services, invest their time and resources at different levels in order to satisfy new customers, retain old customers and cause them to be loyal (1). The attitude of companies and institutions towards developing competition unavoidably focuses on more customer satisfaction for the sale of goods and services and gaining more profit (2). In this regard, Lin, Chen, and Kuan-Shun (2010) suggest that organizations must act better than their competitors in order to achieve their customers and satisfy them (3). With regard to the requirement in today's business environment, organizations are trying to use modern marketing techniques so as to respond to the needs of their customers properly in order to satisfy them in addition to gaining their own profits and competitive advantage (4). Given the importance of the customer in today's competitive environment, numerous researchers believe that several factors affect customer's behavioral interests and maintain them. In this regard, Grönroos (1984) comments that the manner of rendering a service has a direct and positive influence on customer perception of the

*. Corresponding Author:

Nasser Bai

E-mail: nasser_bay@yahoo.com 
perceived service quality and causes a rise in overall customer satisfaction from service provider. Due to countless reasons including profitability, he considers the importance of customers' satisfaction and creating longtime relationships with them vital (5). Rekilä (2013) also states that factors such as fair price, aftersales service, location of purchase, and advertisements are effective on customers' behavioral trends (6). Yavas and Babakus (2010) also suggest that factors such as organizational support of employees, increasing employee commitment, and their customer orientation can result in the formation of positive behavioral outcomes in organization employees which will lead to increased satisfaction and loyalty of customers (7).

Another factor influencing customers' behavioral trends that have attracted the attention of many researchers is innovation in the production of goods and services. Johnson, Dibrell, and Hansen (2009) define innovation as providing a new thing in the organization that can aid in achieving organizational goals (8). From the perspective of Hansen et al. (2006), innovation is creating or accepting new ideas, processes, products, and services that improve customers' value and increase the effectiveness and efficiency of the organizations (9). Huhtala et al. (2014) believe that innovative organizations predict the future needs of their customers and focus on them, draw a picture of success for themselves and evidently define all actions necessary to achieve success (10). Paladino (2007) also believes that innovative organizations have combined their present resources, skills, and competencies of their staff in order to create a new thing (goods or services) and try to achieve competitive advantage by providing new goods and services to their customers (11). Murat Ar and Baki (2011) also suggest that organizations often depend on innovation in processes and innovation in goods and services in order to succeed (12). Serna, Guzman, and Castro (2013) also believe that innovative organizations employ innovation in goods and services, processes, marketing measures, and management to meet the needs of customers, in addition to improving their performance (13). According to Baker and Sinkula (2007), innovation is a comprehensive approach and it must achieve its two ultimate goals which are satisfying and retaining customers and success in the performance of the organization by including all the processes and measures of the organizations. Hence, managers need to identify the factors influencing innovation, so as to provide innovation platform in their organization (14).

One of the factors influencing and facilitating innovation in today's organizations, is market orientation. Market orientation is a term that is nowadays extensively used in marketing literature, as all marketing actions of today's organizations are somehow connected to market orientation (15). Also according to Narver and Slater (1990), market orientation is a set of actions within the organization that create value for the customer which result in profitability and finally help to achieve a sustainable competitive advantage (16). The measures of market orientation of today's organizations are focused on identifying customers' needs. Organizations that respond better and faster to the needs of their customers with their marketing orientation are always ahead of their competitors and possess a greater performance level than others. So no wonder organizations improve their market orientation, hence their performance (17). According to Tsiotsou and Vlachopoulou (2011) market orientation comprises three behavioral components of customer orientation, competitor orientation and coordination between tasks. Customer orientation points out perception and identification of customers and their needs and continually creates value for them. Competitor orientation focuses on accurate recognition of the competitors, including their weaknesses, strength, ability and goals and focus plans. Coordination between tasks also points out things such as the resources and measures of the organization and the relationship between them so as to create value for customers. If the components of market orientation are welldesigned, developed and linked together, the result will be the success of the organization (18).

Different researches have been carried out on market orientation and its consequences in diverse industries. Johnson, Dibrell, and Hansen (2009) studied food companies in America Idaho and concluded that companies successful in market orientation, focus on coordination 
between tasks and innovation within their company and focus on customers' needs and the performance of its competitors in the external environment (8). Carbonell, and Rodríguez Escudero (2010) studied Spanish companies and concluded that market orientation has been effective on both the speed of innovation in these companies and also the success of new products (19). Tsiotsou and Vlachopoulou (2011) studied 216 tourist companies in Greece and came to the conclusion that companies that are successful in market orientation also render better services to their customers (18). Maatoofi and Tajeddini (2011) conducted a research on companies manufacturing car parts in Tehran and concluded that there is a significant relationship between market orientation and innovation of these companies (20). Jiménez-Zarco, Pilar Martínez-Ruiz, and Izquierdo-Yusta (2011) conducted a study on 433 service companies in Spain, which had at least two years of experience, and concluded that the aspects of market orientation has been effective on innovation of services provided in these companies to their customers (17). Results of Kam Sing Wong and Tong research (2012) titled as the impact of market orientation on the success of new products in the electronics industry of China indicated that the aspects of market orientation has been effective on the success of new products (21). Salman (2015) studied service companies in the city of Islamabad in Pakistan and came to the conclusion that the aspects of market orientation have been effective on the innovation of these organizations (22). The findings of Wang (2015) done on 1000 service companies conducted in Taiwan showed that market orientation has been effective on innovation in services in addition to innovation performance of companies being studied (23). Newman, Prajogo, and Atherton (2016) studied 228 services company in Australia and established that market orientation measures of these companies were effective on their innovation strategies (24). Zafar, Hafeez, and Shariff (2016) conducted a research in Pakistan and came to the conclusion that market orientation has been effective on innovation of studied companies. Another part of this study's result revealed that market orientation has enhanced organizational performance via innovation (25). Given the history proposed, it could be inferred that market orientation plays a very significant role in innovation and performance of companies and organizations.

Today, market orientation also has a special place in sports industry. Zheng-lun (2008) in this regard suggests that as a result of customers with different needs, teams and sports organizations significantly require strategies (26). Farrelly, Quester, and Clulow (2008) also argue that market orientation strategies are essential for sports organizations, because their customers' needs and demands are constantly changing and competition in the industry has increased dramatically (27). Beaumont-Kerridge (2001) expresses in this regard that identifying the needs of sports customers' and establishing appropriate relationships with them can increase customers' attraction, satisfaction and loyalty as well as outshining rivals which is the core of market orientation and marketing activities of sports (28).

Finally, knowledge and awareness of the consequences of innovation in sport clubs and sports gyms like bodybuilding clubs can offer acceptable solutions to the success of these bodybuilding clubs. For this purpose, it is necessary to investigate the effect and relationship of factors such as market orientation on innovation of sport clubs and sports gyms. With regard to the tendency of people to sport and particularly the youth, measures based on market orientation such as knowing the precise needs of the athletes, observing and pursuing competitors' measures, and coordinating resources and measures in sport clubs and sports gyms can bring innovation in the services rendered and satisfy athletes, together with positively influencing the performance of the club. Therefore considering the importance of this research, and that since the variables stated are among the factors affecting the performance of sport clubs and sports gyms, and that no investigations have been carried out in this regard, the researcher seeks to answer the question of if there is a significant relationship between market orientation and innovation of bodybuilding clubs of Golestan province?

\section{MATERIALS AND METHODS}

Participants. The population of the study comprised all managers of bodybuilding clubs of 
Golestan province with a license which were 170 persons. The sample was determined using Cochran formula as 119 managers. Based on the viewpoint of Ding et al. (1995) the least sample required to conduct structural equation modeling is between 100 and 150 (29). Participants were selected using stratified random selection method.

Instrumentation. Market orientation questionnaires of Ramayah, Samat, and Lo (2011) and innovation questionnaires of Carmen and María José (2008) were employed for collection of research data $(30,31)$. The questionnaire of Ramayah et al. (2011) comprises 10 statements and three customer orientation components (4 statements), competitor orientation (3 statements) and coordination between tasks ( 3 statements) which is scored based on five-point Likert scale ( $1=$ strongly disagree to $5=$ strongly agree). The innovation questionnaire of Carmen and Maria Jose (2008) consists of 8 questions which is scored based on the 5-point Likert scale ( $1=$ strongly disagree to $5=$ strongly agree). The opinions of 5 members of the sports managing masters were used to determine the validity of research questionnaires and then a pilot study was conducted (i.e. filling questionnaires by 40 persons) in order to determine the reliability of questionnaires and using Cronbach's alpha test the reliability coefficient of these questionnaires was obtained $(\alpha=0.86)$ for market orientation and $(\alpha=0.89)$ for innovation, which indicates the stability of the instrument. Also in another section of the questionnaire, demographic information of managers was collected including age, education and managing experience of bodybuilding clubs. After determining the validity and reliability of measuring instruments and after informing the Board of physical fitness of Golestan province, the questionnaires were distributed among bodybuilding clubs managers and finally 119 questionnaires were collected.

Data Analysis. In this study, descriptive statistics were used in order to organize, summarize, categorize and describe the data including frequency, mean and standard deviation. Structural equation modeling using Smart PLS was employed for data analysis and identification of the effect of research variables.

\section{RESULTS}

Descriptive analysis of the study revealed that most subjects are in the ages of 30 to 40 (56 persons) and their degree of education was mostly bachelor degree (44 persons).

Triple criteria of Fornell and Larcker were considered in order to measure the internal consistency or reliability of structures. The first criterion of reliability is factor loadings of observed variables. The least factor loadings for every observed variable is reported as 0.5 . The results from PLS algorithm showed that the amount of factor loading and $t$ values obtained for the observed variables is significant in 0.01 level (Figure 1). The second criterion of the reliability of structures is Goldstein Dylan coefficient or Composite Reliability (CR) (internal consistency index of measurement model) of structures that should be more than 0.7 (29). The values obtained for this index also presented acceptable reliability of structures (Table 1). The third criterion to evaluate the internal consistency of structures, is the average variance extracted (AVE). The average variance extracted shows the amount of defined variance of latent variables by the observed related variables. Values greater than 0.5 are acceptable for this criterion (29) (Table 2). According to the results from table (1), structures and their markers are of acceptable reliability. This indicates the reliability of research tool used.

Table 1. Indicators for examining reliability of research structures

\begin{tabular}{cccccc}
\hline Structures & AVE & CR & R Square & Cronbachs Alpha & Communality \\
\hline Customer Orientation & 0.54 & 0.82 & - & 0.71 & 0.54 \\
\hline Competitor Orientation & 0.55 & 0.78 & - & 0.57 & 0.55 \\
\hline Coordination Between Tasks & 0.61 & 0.82 & - & 0.69 & 0.61 \\
\hline Innovation & 0.50 & 0.89 & $\mathbf{0 . 2 8}$ & 0.85 & 0.50 \\
\hline
\end{tabular}


To evaluate the diagnostic validity or divergent research structures, Chin (1998) suggests that the square root of AVE of a structure should be greater than the correlation of that structure with that of other structures (32). According to the results from table (2), it can be stated that the structures examined in this study possess good diagnostic validity (Table 2 ).
Also in order to examine the quality or fitness of the measurement model, Sivo et al. (2006) suggest validity examination index of sharing (33). Positive values of this index show good quality of measurement tools (Figure 1). Based on this and the results from table (1), instruments used in this study are of good quality.

Table 2. The results of examination of the diagnostic validity of research structures

\begin{tabular}{lccccc}
\hline Structures & $\begin{array}{c}\text { Customer } \\
\text { Orientation }\end{array}$ & $\begin{array}{c}\text { Competitor } \\
\text { Orientation }\end{array}$ & $\begin{array}{c}\text { Cordination Between } \\
\text { Tasks }\end{array}$ & Innovation \\
\hline 1 & Customer Orientation & ${ }^{*} \mathbf{0 . 7 4}$ & & & \\
\hline 2 & Competitor Orientation & 0.50 & ${ }^{*} \mathbf{0 . 7 4}$ & & \\
\hline 3 & $\begin{array}{c}\text { Coordination Between } \\
\text { Tasks }\end{array}$ & 0.51 & 0.53 & $\mathbf{0 . 7 8}$ & \\
\hline 4 & Innovation & 0.52 & 0.51 & 0.56 & $* \mathbf{0 . 7 1}$ \\
\hline
\end{tabular}

*: Square root of the AVE.

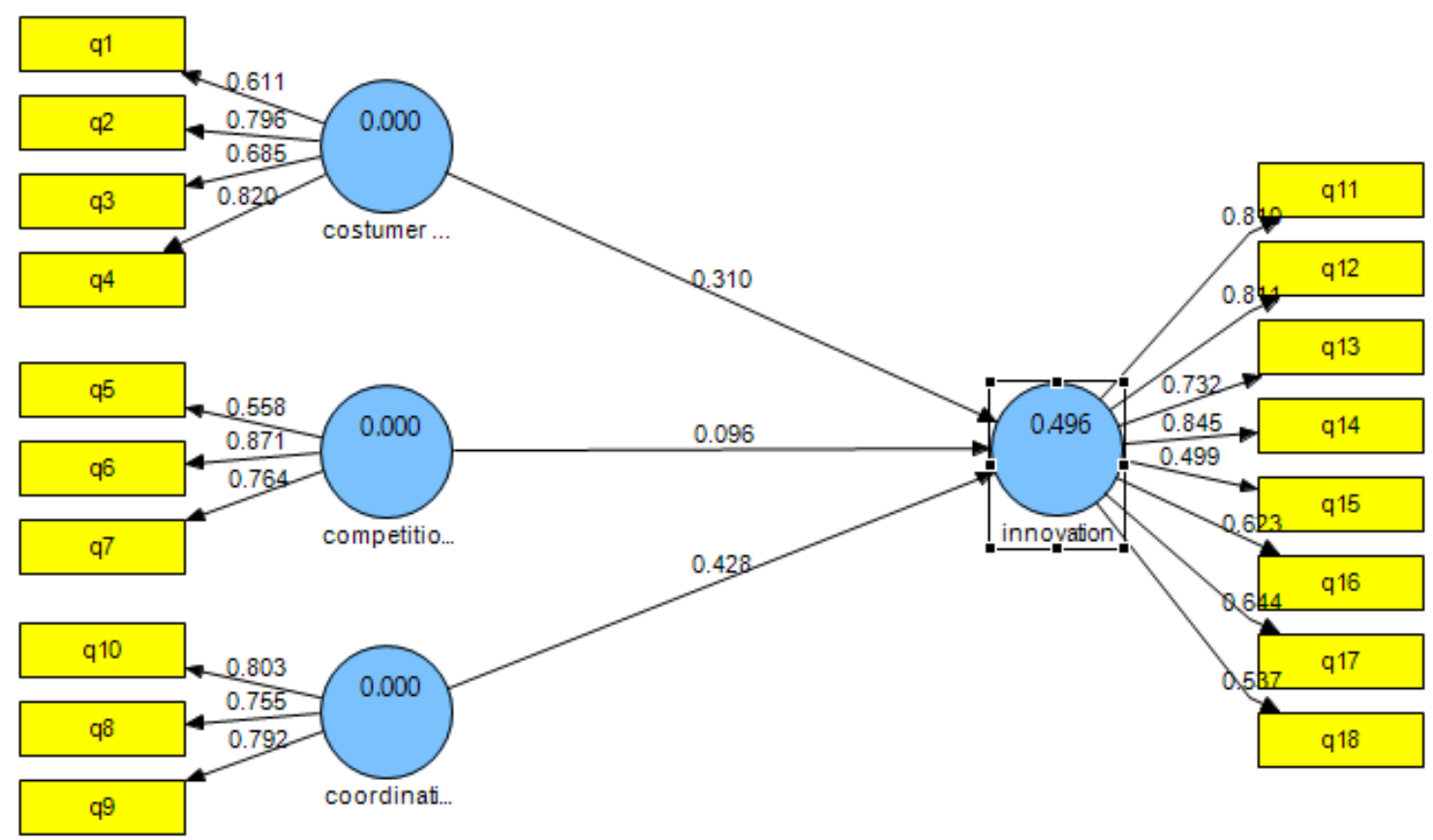

Figure 1. Tested model of study in standard estimation

The results from the test of research model revealed that the effects of customer orientation was meaningful on innovation $(\beta=0.31, t=3.39)$. Other research findings showed that competitor orientation variable has no meaningful effect on innovation of bodybuilding clubs $(\mathrm{t}=1.06$, $\beta=0.09$ ). The results from structural equation modeling of research variables revealed that the component of coordination between tasks, has a positive effect and is meaningful on innovation of bodybuilding clubs $(\mathrm{t}=3.87, \quad \beta=0.43)$. According to the results from table (1) and 
obtained values for determining coefficient, it research, completely determine $28 \%$ of changes could be stated that predictor variables of the

of innovation variable.

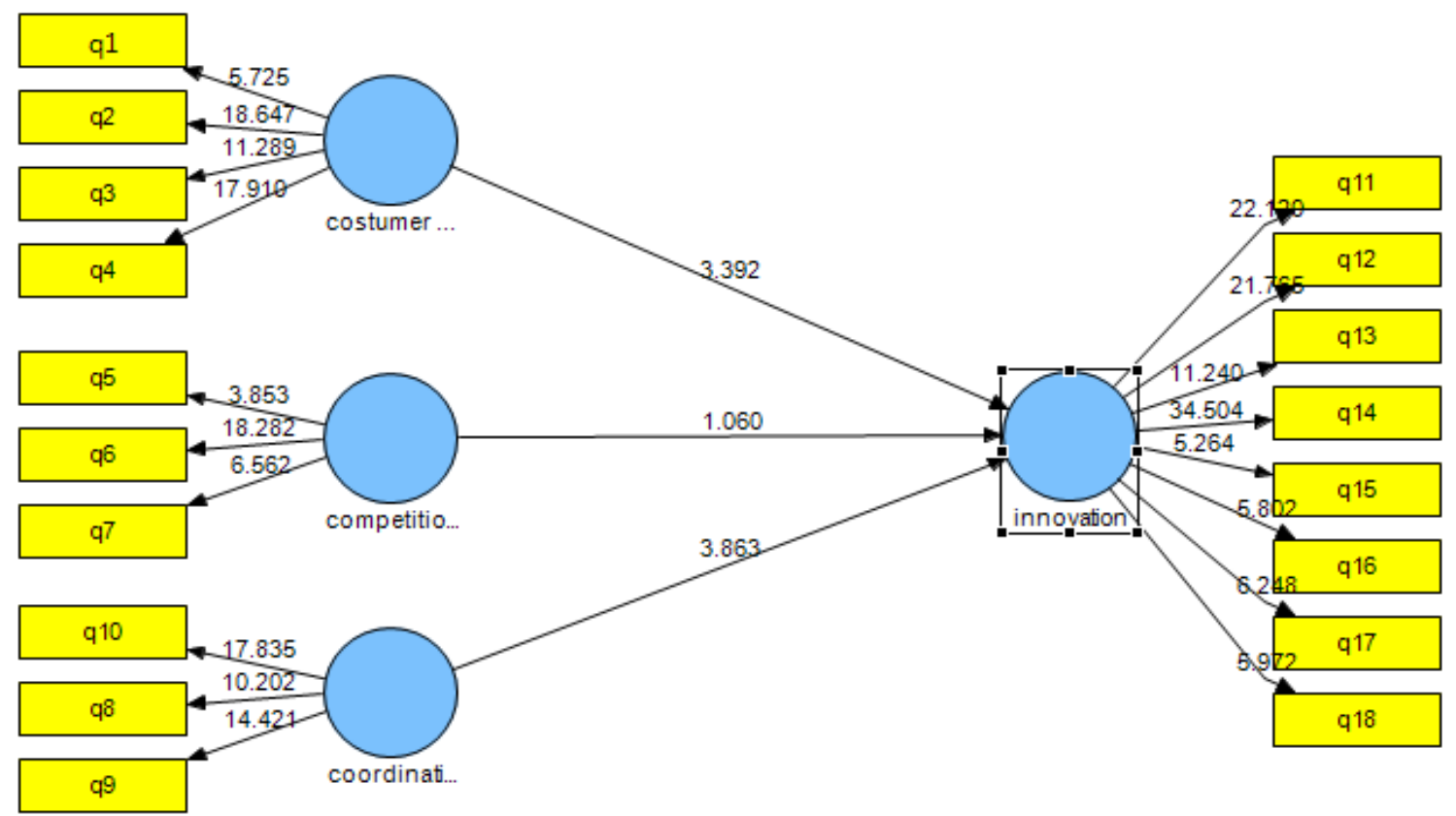

Figure 2. Tested model in the study in mean numbers

Table 3. Effect of predictor variables on criterion variables of the research

\begin{tabular}{ccc}
\hline \multirow{2}{*}{ The criterion variable } & \multicolumn{2}{c}{ Statistics } \\
\cline { 3 - 4 } & $\mathrm{t}$ & $\beta$ \\
\hline Customer orientation on innovation & 3.39 & 0.31 \\
\hline Competitor orientation on innovation & 1.06 & 0.09 \\
\hline Coordination between tasks on innovation & 3.86 & 0.43 \\
\hline
\end{tabular}

$-1.96 \leq t$ value $+\leq 1.96$

\section{DISCUSSION}

The aim of the current study was to examine the role of market orientation in innovation of bodybuilding clubs in Golestan province. The results revealed that customer orientation has a meaningful impact on innovation of bodybuilding clubs of Golestan province from the perspective of their managers. This result was in agreement with previous results by Johnson, Dibrell, and Hansen (2009), Maatoofi and Tajeddini (2011), Jiménez-Zarco, Pilar Martínez-Ruiz, and Izquierdo-Yusta (2011), Serna, Guzman, and Castro (2013), Salman (2015), and Wang (2015) (8, 13, 17, 20, 22, 23). At the present time, customer's choice has been expanded and thus companies and firms have to pay attention to the needs and interests of customers at first (29). According to Johnson, Dibrell, and Hansen (2009), since marketing is the science of success in attracting and keeping customers in competitive markets, industrial managers are currently trying to apply marketing principles, so as to guarantee their success beforehand. Complete understanding of marketing concepts and proper application of those principles can be helpful in improving the competitiveness of companies and organizations (8). Thus paying attention to the obvious and hidden customers' needs can lead to the design and delivery of new and desired goods and 
services. It is evident that any organization which acts better under this circumstance, would achieve greater success (9). The ability of customer orientation of an organization is inside the assumptions related to organization's customer satisfaction, efficiency and its financial performance. Lin, Chen, and Kuan-Shun Chiu (2010) also stated that on the basis of marketing theories, an organization that wishes luck should make all their efforts to satisfy the needs and demands of their customers or in other words, move towards profitable management of customer demands. This implies that organizations have to present and maintain customer value in a more effective way than their competitors (3). Organizations that do so are described with terms such as marketoriented, customer driven, customer-oriented etc. Such organizations use the knowledge of customers' needs and continually try to use innovation in their products and services to meet their customers' needs.

The result revealed that competitor orientation had no effect on innovation of bodybuilding clubs of Golestan province. This result is not consistent with previous results by, Johnson, Dibrell, and Hansen (2009), Maatoofi and Tajeddini (2011), Jiménez-Zarco, Pilar Martínez-Ruiz, and Izquierdo-Yusta (2011), Serna, Guzman, and Castro (2013), Salman (2015), and Wang (2015) (8, 13, 17, 20, 22, 23). The rationale behind this inconsistency may be due to the fact that with increasing competition in the sports industry of our country, sports clubs pay less attention to their competitors and their measures. Therefore, to overcome these competitors, they also have to monitor their performance and be ahead of them. According to Kam Sing Wong and Tong (2012), today's organizations are experiencing a new era of competition that this competition has resulted to the destruction of many organizations, thus managers in today's organizations should always monitor their competitive performance in their industry so as to maintain their share of the market and gain a greater share than their competitors. This makes managers to always consider the outside context and configure inner context of their organization with the needs of outside context which could form innovation in the organization and eventually its success (21).
Serna, Guzman, and Castro (2013) in this regard mention that a part of market orientation of organizations must be focused on the performance of competitors. Organizations should always provide new information regarding the performance of their competitors so as to have a better competition and to be innovative. Awareness of objectives, strategies, and marketing measures of competitors can provide valuable information for the organization and result in the formation of new ideas for the production of goods and services, which can eventually outshine rivals (13). Innovative organizations and companies are always learning and a part of the learning is accomplished by evaluating the actions of their competitors. Hence, innovative organizations and companies alongside compliance with ethical issues must be able to constantly upgrade their capabilities to better compete with their competitors.

The results indicated that the effect of coordination between the tasks on innovation of bodybuilding clubs of Golestan province from the perspective of its managers is positive and significant. This result is consistent with previous results by Johnson, Dibrell, and Hansen (2009), Maatoofi and Tajeddini (2011), Jiménez-Zarco, Pilar Martínez-Ruiz, and Izquierdo-Yusta (2011), Serna, Guzman, and Castro (2013), Salman (2015), and Wang (2015) $(8,13,17,20,22,23)$. According to Wang (2015), one of the most important factor affecting innovation of organizations and companies, are organizational inner and outer factors (23). Organization's goals and strategies in every aspect should be based on capabilities and weaknesses of inner context and opportunities and threats of outer context (12). Innovative organizations have always equipped their manpower with knowledge and driven them towards better and further learning. Such organizations create some changes in their structures, eliminate barriers to innovation and encourage people to provide brand ideas. Such organizations also provide coordination between various aspects and managers apply necessary support towards their staff (17). Paying attention towards marketing strategies and combining it with organizational factors can provide the context for innovation in organizations and 
companies, which suggests adequate attention of the managers to these issues.

Results revealed that the effect of competitor orientation on innovation of bodybuilding clubs of Golestan province is insignificant, thus proper identification of key customers, exact recognition of the needs and demands of major customers, establishing a system for managing customer link, creating a database to store customers information, making the most use of electronic communications channels with customers including website and email, paying attention to the criticism and complaints from customers, pinpointing the correct strategies of marketing in bodybuilding clubs of Golestan province by their managers, using knowledge manpower and coaches in bodybuilding clubs of Golestan province, rendering new services in bodybuilding clubs of Golestan province, evaluating the actions of bodybuilding clubs of Golestan province on the basis of pre-determined objectives and strategies, accurate identification of competitors and exact assessment of their actions and performance are recommended.

\section{CONCLUSION}

Through the present study and other studies in this field it can be concluded that market orientation is effective on numerous organizational variables. Although in this study the effect of market orientation on innovation of bodybuilding clubs of Golestan province was investigated, but market orientation is also effective on other variables, including performance, employee satisfaction, employee engagement which can be considered as limitations of the study.

\section{APPLICABLE REMARKS}

- Bodybuilding clubs' managers pay more attention to the needs of customers through innovative measures to manage.

- It is suggested that bodybuilding clubs managers' increase innovative behaviors of their employees through coordination between the tasks.

\section{REFERENCES}

1. Kwon HH, Trail G, James JD. The mediating role of perceived value: Team identification and purchase intention of team-licensed apparel. Journal of Sport Management. 2007;21(4):540-54.

2. Elahi S, Heidari B. Customer relationship management. Tehran, Iran: Institute of Business Studies and Research; 2005 [Book in Farsi].

3. Lin RJ, Chen RH, Kuan-Shun Chiu K. Customer relationship management and innovation capability: an empirical study. Industrial Management \& Data Systems. 2010;110(1):111-33.

4. Xie D. Exploring organizational learning culture, job satisfaction, motivation to learn, organizational commitment, and internal service quality in a sport organization. USA: The Ohio State University; 2005.

5. Grönroos C. A Service Quality Model and its Marketing Implications. European Journal of Marketing. 1984;18(4):36-44.

6. Rekilä T. A study of the factors influencing customer satisfaction and efficiency in contact centers: the combined effect: Aalto University; 2013.

7. Yavas U, Babakus E. Relationships between organizational support, customer orientation, and work outcomes: A study of frontline bank employees. International Journal of Bank Marketing. 2010;28(3):222-38.

8. Johnson AJ, Dibrell CC, Hansen E. Market orientation, innovativeness, and performance of food companies. Journal of Agribusiness. 2009;27(1/2):85-106.

9. Hansen E, Korhonen S, Rametsteiner E, Shook S. Current state-of-knowledge: Innovation research in the global forest sector. Journal of Forest Products Business Research. 2006;3(4).

10. Huhtala J-P, Sihvonen A, Frösén J, Jaakkola M, Tikkanen H. Market orientation, innovation capability and business performance: Insights from the global financial crisis. Baltic Journal of Management. 2014;9(2):134-52.

11. Paladino A. Investigating the Drivers of Innovation and New Product Success: A Comparison of Strategic Orientations*. Journal of Product Innovation Management. 2007;24(6):534-53.

12. Murat Ar I, Baki B. Antecedents and performance impacts of product versus process innovation: Empirical evidence from SMEs located in Turkish science and technology parks. European Journal of Innovation Management. 2011;14(2):172-206. 
13. Serna MdCM, Guzman GM, Castro SYP. The Relationship between Market Orientation and Innovation in Mexican Manufacturing SME's. Advances in Management and Applied Economics. 2013;3(5):125-37.

14. Baker WE, Sinkula JM. Does Market Orientation Facilitate Balanced Innovation Programs? An Organizational Learning Perspective. Journal of Product Innovation Management. 2007;24(4):316-34.

15. Kohli AK, Jaworski BJ. Market Orientation: The Construct, Research Propositions, and Managerial Implications. Journal of Marketing. 1990;54(2):1-18.

16. Narver JC, Slater SF. The Effect of a Market Orientation on Business Profitability. Journal of Marketing. 1990;54(4):20-35.

17. Jiménez-Zarco AI, Pilar Martínez-Ruiz M, Izquierdo-Yusta A. The impact of market orientation dimensions on client cooperation in the development of new service innovations. European Journal of Marketing. 2011;45(1/2):43-67.

18. Tsiotsou RH, Vlachopoulou M. Understanding the effects of market orientation and e-marketing on service performance. Marketing Intelligence \& Planning. 2011;29(2):141-55.

19. Carbonell P, Rodríguez Escudero AI. The effect of market orientation on innovation speed and new product performance. Journal of Business \& Industrial Marketing. 2010;25(7):501-13.

20. Maatoofi AR, Tajeddini K. Effect of market orientation and entrepreneurial orientation on innovation: Evidence from auto parts manufacturing in Iran. Journal of Management Research. 2011;11(1):20-30.

21. Kam Sing Wong S, Tong C. The influence of market orientation on new product success. European Journal of Innovation Management. 2012;15(1):99-121.

22. Salman AS. The Effect of Market Orientation on Product Innovation. IOSR Journal of Business and Management (IOSR-JBM). 2015;17(4):40-6.

23. Wang C-H. The Impact of Market Orientation on Innovation Performance: Does Service Innovation Matter? Journal of Business Studies Quarterly. 2015;6(3):77-93.

24. Newman A, Prajogo D, Atherton A. The influence of market orientation on innovation strategies. Journal of Service Theory and Practice. 2016;26(1):72-90.

25.Zafar H, Hafeez MH, Shariff MNM. Relationship between market orientation, organizational learning, organizational culture and organizational performance: mediating impact of innovation. South East Asia Journal of Contemporary Business, Economics and Law. 2016;9(2):40-56.

26.Zheng-lun W. To Enhance the Running Competitiveness of Sport Institutes with Market-Orientation and Character Exploration_ O Options on Specialty Adjustment in Sport Institutes [J]. Journal of Nanjing Institute of Physical Education (Social Science). 2008;3:[Article in Chinese_English Abstract].

27. Farrelly F, Quester P, Clulow V. Exploring Market Orientation and Satisfaction of Partners in the Sponsorship Relationship. Australasian Marketing Journal (AMJ). 2008;16(2):51-66.

28. Beaumont-Kerridge J. Market orientation and service quality of public sector sport and recreation providers: a case study approach. London, UK: Middlesex University; 2001.

29. Ghasemi V. Introduction to structural equation modeling. Tehran, Iran: Sociologists Publication; 2009 [Book in Farsi].

30. Carmen C, María José G. The role of technological and organizational innovation in the relation between market orientation and performance in cultural organizations. European Journal of Innovation Management. 2008;11(3):413-34.

31. Ramayah T, Samat N, Lo MC. Market orientation, service quality and organizational performance in service organizations in Malaysia. Asia-Pacific Journal of Business Administration. 2011;3(1):8-27.

32. Chin WW. Commentary: Issues and Opinion on Structural Equation Modeling. MIS Quarterly. 1998;22(1):viixvi.

33. Sivo SA, Fan X, Witta EL, Willse JT. The Search for "Optimal" Cutoff Properties: Fit Index Criteria in Structural Equation Modeling. The Journal of Experimental Education. 2006;74(3):267-88. 